\title{
Foliar DMSO:DMSP ratio and metal content as indicators of stress in Spartina alterniflora
}

\author{
Caroline R. McFarlin, Merryl Alber* \\ Department of Marine Sciences, University of Georgia, Athens, Georgia 30602, USA
}

ABSTRACT: We evaluated 2 potential indicators of stress, viz. the ratio of dimethylsulfoxide to dimethylsulfoniopropionate (DMSO:DMSP) and foliar metals, in Spartina alterniflora collected from areas affected by 4 different disturbances (sudden marsh dieback, horse grazing, increased snail densities, wrack deposition) across 20 marshes in Georgia, USA. The DMSO:DMSP ratio was a stronger and more consistent indicator of stress than either DMSP or DMSO concentrations alone, with significantly higher ratios occurring in leaves and stems collected from affected compared to healthy areas in all 4 disturbance types. Foliar metal concentrations also differed in affected compared to healthy areas. Of 20 metals evaluated, concentrations of 19 were increased in leaves collected from edge and affected areas. Multidimensional scaling using the entire suite of metals showed separation between plants from affected and healthy areas, but no difference among disturbance types. In contrast, chlorophyll a concentrations were not significantly different between affected and healthy areas, and did not correlate with variation in either of the 2 indicators. These results suggest that the DMSO:DMSP ratio and foliar metal suite are sensitive indicators of sublethal stress in Spartina, capable of identifying stress before there are visible signs such as chlorophyll loss. The fact that both indicators were consistent across a variety of disturbance types suggests that they may be primarily responsive to general oxidative stress and thus, broadly useful tools for evaluating the health of salt marsh habitat in the field.

KEY WORDS: Smooth cordgrass - Dimethylsulfoniopropionate - Dimethylsulfoxide · Salt marsh . Disturbance $\cdot$ Sudden dieback

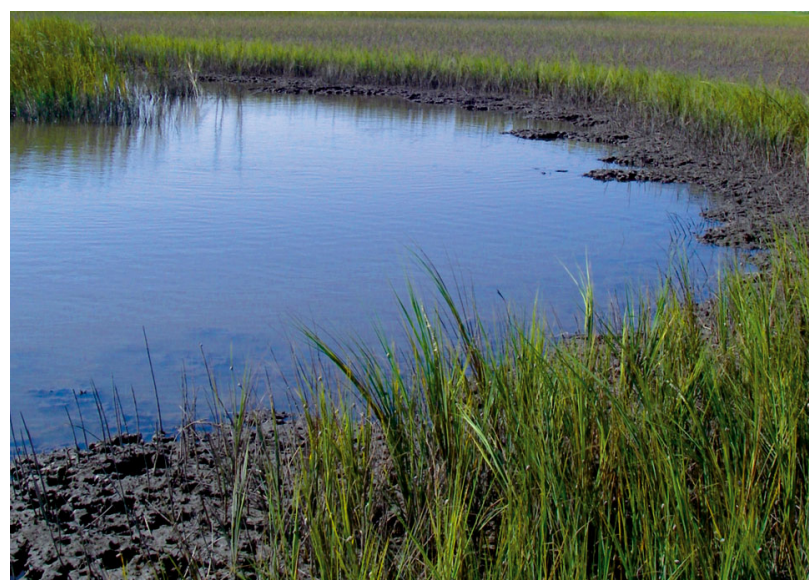

Spartina alterniflora salt marsh near St. Simons Island, GA, with a dieback area along the edge of the tidal creek.

Photo: C. McFarlin

\section{INTRODUCTION}

Spartina spp. are important wetland plants occurring in temperate salt marshes worldwide, with $S$. alterniflora dominant along the entire US Gulf and Atlantic coasts. These species play a disproportionately critical role in salt marshes by ameliorating chemical and physical stresses to other wetland plants and animals, functioning as essential habitat and refugia from predators, and providing a source of organic matter for associated fauna as a trophic base (Pennings \& Bertness 2001). Spartina marshes are also important for storm protection, water purification, and erosion control. Salt marshes can be subject to a wide range of natural and anthropogenic disturbances, all of which can affect the services provided by Spartina spp. 
Two common disturbances that affect salt marshes are wrack deposition and herbivore overgrazing (Pennings \& Bertness 2001). Wrack is capable of completely killing Spartina alterniflora when it becomes stranded on the marsh surface (often following storm surges) or when it is blocked by docks and other physical barriers (Valiela \& Rietsma 1995, Alexander 2008). Overgrazing can also lead to bare patches in the marsh. These can result from the introduction of non-native species (e.g. nutria: Evers et al. 1998; feral horses: Turner 1987; feral cattle: Martin 2003), from the absence or reduction of predators which leads to increased herbivore populations (e.g. littorinid snails: Silliman \& Bertness 2002; sesarmid crabs: Holdredge et al. 2009), and from agricultural subsidies that enhance food supply to herbivore populations (e.g. geese: Jefferies et al. 2004). More recently, sudden dieback has resulted in the loss of salt marsh vegetation in areas along the entire US Eastern Atlantic Seaboard and Gulf Coasts since 2000 (reviewed by Alber et al. 2008). The onset of sudden dieback is indicated by a rapid yellowing and browning of $S$. alterniflora in standing position followed by a complete loss of vegetation over the course of a few months (McKee et al. 2004, Alber et al. 2008). To date, no single factor has been linked to sudden dieback; rather, it has been described as a multi-stressor disturbance associated with drought (McKee et al. 2004, Silliman et al. 2005, Alber et al. 2008).

The most obvious and frequently studied response to disturbances in salt marshes has been the degradation and loss of plant biomass (Turner 1987, Baldwin \& Mendelssohn 1998, Ewanchuk \& Bertness 2003); however, physiological responses may occur long before there are visible signs of stress (Mendelssohn \& McKee 1992). Moreover, the effects of many disturbances, such as increases in flooding frequency, pollutant contamination, and introduced species, can occur gradually and be difficult to detect (Mendelssohn \& McKee 1992, Weilhoefer 2011). If we can identify early signs of stress in marshes, we will be in a better position to identify areas that are at risk and potentially preserve valuable habitat.

Currently, no consistent, sensitive measures are available that can be used to indicate Spartina stress under multi-stressor conditions that exist in the field. Numerous physiological indicators (adenine nucleotides, proline concentrations, $\mathrm{CO}_{2}$ uptake, water use efficiencies, alcohol dehydrogenase activities, and leaf spectral reflectances) have been evaluated in Spartina spp. subject to individual stressors such as salinity, nutrient, and metal stress (Mendelssohn \&
McKee 1992, Ewing et al. 1995a,b, Mendelssohn et al. 2001). However, these metrics have primarily been evaluated under manipulated greenhouse conditions and have translated poorly as consistent signals of stress in the field (Ewing et al. 1997). Many of the indicators are stressor-specific: glutathione is best suited for evaluating plants suspected of metal contamination (Mendelssohn \& McKee 1992, Pennings et al. 2002), proline is better at identifying salinity stress, and nutrient stress may be identified via altered leaf spectral reflectance, $\mathrm{CO}_{2}$ uptake, or adenine nucleotide levels (Ewing et al. 1995a,b). There have also been discrepancies in the ability of various indicators to respond to similar disturbances across different field studies. Padinha et al. (2000) found higher concentrations of metal-chelating thiolic proteins and lower photosynthetic efficiencies in Spartina alterniflora from polluted areas of the Ria Formosa lagoon in Portugal, whereas Pennings et al. (2002) found no differences in these same indicators in polluted versus healthy areas of South Carolina, USA, marshes.

Studies in sudden dieback areas have reported 2 different types of physiological responses in Spartina alterniflora plants that may reflect general (oxidative) stress: lower concentrations of dimethylsulfoniopropionate (DMSP) and increased concentrations of metals $(\mathrm{Fe}, \mathrm{Al})$ were found in leaves of $S$. alterniflora collected near dieback areas as compared to healthy marsh areas in South Carolina and Louisiana, respectively (McKee et al. 2004, Kiehn \& Morris 2010). DMSP is a secondary metabolite synthesized by $S$. alterniflora from the amino acid methionine, and has been speculated to be an herbivore deterrent/attractant, a sulfur detoxifying agent, and an antioxidant (Kocsis et al. 1998, Sunda et al. 2002, Husband \& Kiene 2007). Recent work supports an antioxidant role of DMSP in $S$. alterniflora, in that there was direct conversion to its oxidation product, dimethylsulfoxide (DMSO), and thus a higher DMSO:DMSP ratio in yellowing and experimentally stressed plants compared to healthy plants (Husband \& Kiene 2007, Husband et al. 2012). The increased concentrations of foliar metals in $S$. alterniflora near dieback areas may have been a direct consequence of altered environmental conditions caused by drought, leading to acidic and oxidizing marsh soil conditions (McKee et al. 2004). Metals often become more soluble and bioavailable to vegetation in drained, aerated marsh soils (Portnoy 1999) or when there has been a change in soil biochemistry (especially of $\mathrm{pH}$ and $\mathrm{Eh}$; Kashem \& Singh 2001). It is unclear whether these 2 potential indicators (metal concentration and the 
DMSO:DMSP ratio) may also apply to other situations where $S$. alterniflora is stressed due to other disturbances.

It would be valuable to identify a generic indicator, capable of detecting plant stress in the field across a variety of conditions, even when the specific cause of 'stress' is unknown. An indicator that is responsive before visible symptoms appear (such as the loss of chlorophyll) would be particularly useful. Using a natural field experiment, we examined the DMSO: DMSP ratio, metal concentrations, and chlorophyll concentrations in Spartina alterniflora collected from sudden dieback areas, and in areas subject to 3 other salt marsh disturbances: wrack deposition, herbivory by littorinid snails, and herbivory by horses. Our goal was to test whether the DMSO:DMSP ratio and metal concentrations were useful as generic indicators of stress under varied field conditions, and whether the response was consistent, regardless of disturbance type.

\section{MATERIALS AND METHODS}

\section{Study sites}

In the fall of 2008 and 2009, we sampled 20 salt marshes along the Georgia coast that had areas experiencing a loss of Spartina alterniflora: 5 with a high snail density, 5 with wrack accumulation, 5 with damage by horses, and 5 sudden dieback sites. Sites were located on Sapelo Island, Cumberland Island, and in Meridian and Brunswick (Fig. 1). All disturbed areas were chosen based on the presence of an S. alterniflora monoculture. Snail sites had unusually heavy snail densities in the disturbed areas (overall site mean \pm SE $452 \pm 117$ snails $\mathrm{m}^{-2}$ ), which were close to the levels that had been previously reported to lead to loss of vegetation in Georgia ( 600 snails $\mathrm{m}^{-2}$, Silliman \& Bertness 2002). Wrack sites were areas that had visible plant debris accumulated on the salt marsh surface $(\sim 5 \mathrm{~cm}$ thick), with no other known disturbance factors. Horse sites were located in areas identified as frequently grazed by horses at Cumberland Island National Seashore according to the observations of the National Park Service Rangers. Sudden dieback sites were locations that had been reported to the Georgia Department of Natural Resources, Coastal Resources Division (Brunswick) following the 2000-2001 droughts in Georgia, or were observed on Sapelo Island by Georgia Coastal Ecosystems Long Term Ecological Research personnel.

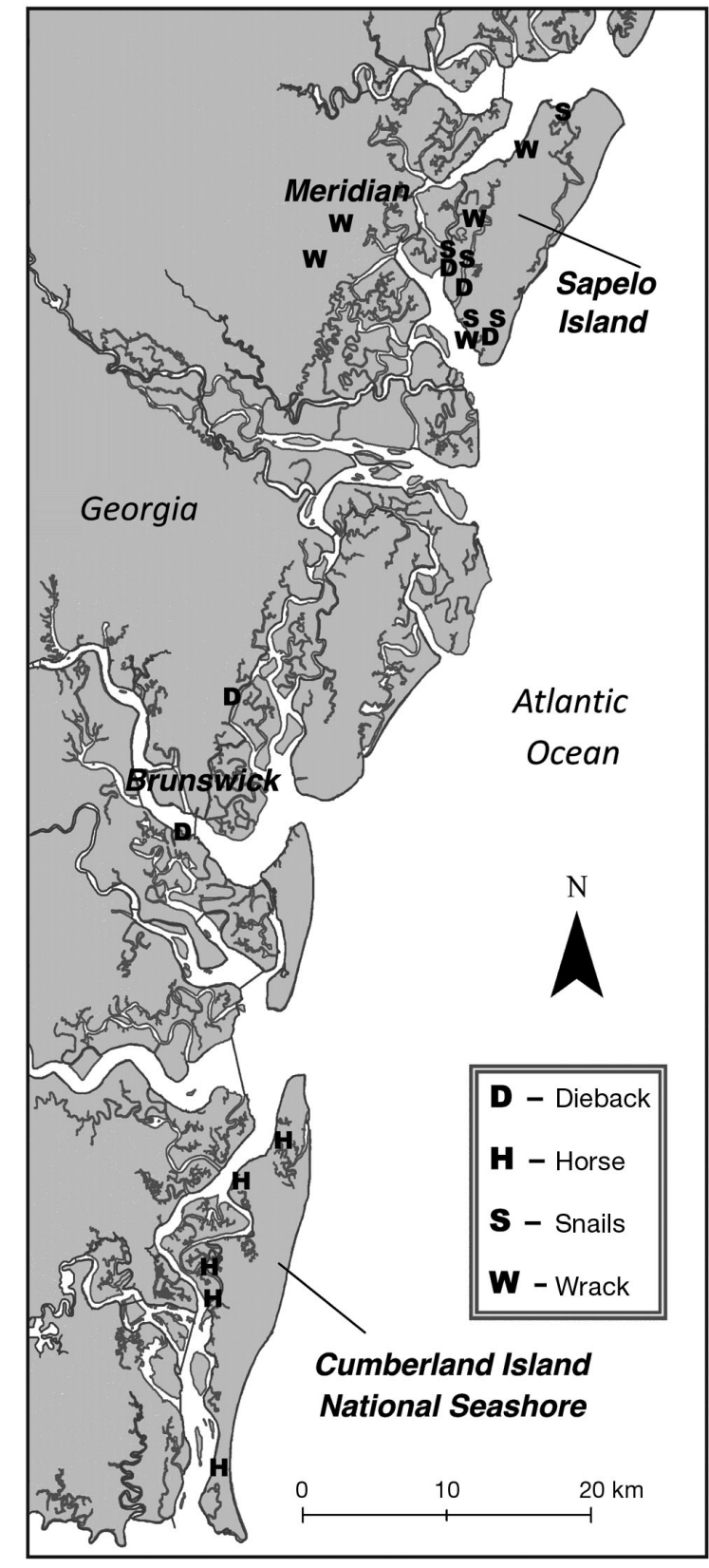

Fig. 1. Spartina alterniflora. Location of the dieback, horse, snail, and wrack sites along the Georgia coast (5 sites per disturbance type; see 'Materials and methods' for details of the disturbance types). At each site, plants were sampled haphazardly to test tissue DMSP, DMSO, chlorophyll, and metal concentration, from within the healthy, edge of affected, and affected marsh

\section{Sample collection}

We sampled plants in 3 zones at each site: the 'affected' zone, which included the areas where Spartina alterniflora was damaged (e.g. remaining rhizome stubble or standing dead plants, visible injuries due to 
radulation or grazing) and visible agents of disturbance were often present (wrack, snails, horses); along the 'edge' of the affected area; and a nearby 'healthy' area (generally $10 \mathrm{~m}$ away from the edge of the affected area, with no visible effects of disturbance). The rationale for including the 'edge zone' was to examine $S$. alterniflora in an area that did not appear visibly stressed, yet might still experience negative effects from the nearby disturbed areas (e.g. through rhizomes of $S$. alterniflora or through the loss of neighboring plants that typically ameliorate edaphic stressors; Bertness \& Shumway 1993). In addition, $S$. alterniflora leaves and stems were already completely lost in the 'affected zone' at all dieback sites (except for 1 stem at 1 site), and $S$. alterniflora leaves were lost in the 'affected zone' at 2 of the snail sites, so the 'edge zone' also provided an intermediate level of a disturbance from which to obtain plant samples.

At each site, 3 individual Spartina alterniflora plants were haphazardly selected from within each zone (except where plants were absent in the affected zone) for the analysis of DMSP, DMSO, and chlorophyll concentrations. Intact plants, which were located at least 5 to $10 \mathrm{~m}$ apart, were removed with root material, carefully transported upright in moist soil to the laboratory, rinsed in deionized water to remove bacterial and algal growth, and prepared for immediate analysis or frozen at $-80^{\circ} \mathrm{C}$ (for $\leq 6 \mathrm{mo}$ ) within $48 \mathrm{~h}$ of collection. Plants were then clipped into leaf, stem, and root sections for analysis. Because the physical condition of plants varied, we clipped samples from the best 2 of 3 plants based on color and vigor and noted the leaf color. Leaves and stems for measurements of DMSP, DMSO, and chlorophyll concentrations were clipped from the same section of each plant as follows: a small section of leaf $(\sim 0.5 \mathrm{~cm}$ length) was clipped from the middle of the youngest fully expanded leaf (typically the second or third leaf from the top), and a small section of stem $(\sim 0.5 \mathrm{~cm}$ length) was clipped at mid-height of the plant. Roots were clipped for measurements of DMSP and DMSO near the attachment to the rhizome.

For the analysis of metal content, only living leaves (at least $75 \%$ green) were used, as previous studies have shown that metals $(\mathrm{Cu}, \mathrm{Pb}, \mathrm{Zn})$ accumulate as Spartina alterniflora leaves get older and senesce (Weis et al. 2003). Where possible, we used the portion of leaf that remained after clipping for DMSO, DMSP, and chlorophyll analysis, as well as the entire length of the next youngest fully expanded green leaf. Leaves were pooled across the 2 replicate plants collected per zone at each site, and dried at $60^{\circ} \mathrm{C}$ until they reached a constant weight.

\section{Foliar DMSP, DMSO, and DMSO:DMSP ratio}

Leaves and stems (10.0 to $50.0 \mathrm{mg}$ pieces, weighed to the nearest $0.1 \mathrm{mg}$ ) were weighed and placed into $30 \mathrm{ml}$ serum vials (Wheaton, $37.4 \mathrm{ml}$ of headspace), sealed with gas-tight septa and aluminum crimp tops. The concentration of cellular DMSP and DMSO was measured by converting each to DMS gas, separately. DMSP was converted to DMS gas by injecting $1 \mathrm{ml}$ of $5 \mathrm{M} \mathrm{NaOH}$ into the serum vials, and incubating upside-down in the dark for a period of $24 \mathrm{~h}$ at $30^{\circ} \mathrm{C}$ (without shaking). The methods for DMSO conversion were similar, except that $0.5 \mathrm{ml}$ of $20 \% \mathrm{TiCl}_{3}$ was added to vials and incubation was for a period of $2 \mathrm{~h}$ at $50^{\circ} \mathrm{C}$ (without shaking). Following incubation, $0.2 \mathrm{ml}$ (for DMSP analysis) or $0.5 \mathrm{ml}$ (for DMSO analysis) of headspace gas from the serum vials was injected into a flame photometric detector gas chromatograph (SRI 8610-C with a Chromosil 330 column with nitrogen as the carrier gas) and analyzed for DMS area using the PeakSimple Program. In each case, 2 subsamples each for DMSP and DMSO were analyzed as independent analytical replicates from a single plant sample.

Standard curves to relate peak area to DMS gas were obtained by injecting the GC with DMS gas liberated from known amounts of DMSP or DMSO standard stocks that were converted to DMS gas using similar volumes of $\mathrm{NaOH}$ and $\mathrm{TiCl}_{3}$ as used for the samples. It was assumed that all DMSP or DMSO was converted to DMS gas, and that the DMS present as headspace gas or dissolved in the liquid volume (based on Henry's solubility coefficient constant) of the serum vial was primarily due to direct liberation of foliar DMSP and DMSO (DMS present in Spartina leaves could also contribute a very minor proportion of the DMS gas measured in the vial). The foliar concentration of DMSP and DMSO in $\mu \mathrm{mol} \mathrm{g}^{-1}$ tissue (fresh weight, FW) was determined by dividing the concentration of DMS gas in the serum vial by the weight of plant tissue. Blank controls for each were monkey grass Ophiopogon japonicus and deionized water, and positive controls of DMS gas were liberated from DMSO standards. Controls were treated and injected identically to samples.

\section{Chl $a$ and phaeo a concentrations}

Leaves and stems (10.0 to $50.0 \mathrm{mg}$ pieces, weighed to the nearest $0.1 \mathrm{mg}$ ) were macerated with a tissue grinder, extracted in $90 \%$ acetone, and centrifuged at $2200 \times g(10 \mathrm{~min})$. The fluorescence of the super- 
natant was measured before and after acidification with $10 \% \mathrm{HCl}$ on a Turner Designs 10-AU fluorometer following US Environmental Protection Agency Method 445.0 (Arar \& Collins 1997). High and low value liquid chlorophyll standards with certified spectrophotometer (Abs) readings were used to assign concentration values to fluorometer measurements. Fluorometer readings were converted to chlorophyll a (chl a) and phaeophytin a (phaeo a) per gram of tissue (FW). In each case, 2 subsamples were analyzed as independent analytical replicates from a single plant sample and then averaged.

\section{Leaf metals}

Dried leaves were ground in a Wiley mill (mesh no. 40), burned at $500^{\circ} \mathrm{C}$ for $4 \mathrm{~h}$, and amended with a plant buffer solution $\left(30 \% \mathrm{HCl}, \mathrm{v} / \mathrm{v} ; 10 \% \mathrm{HNO}_{3}, \mathrm{v} / \mathrm{v}\right.$; and $20 \mathrm{ppm}$ of molybdenum) at a ratio of 1:10, sample (ash):buffer. Samples were analyzed for a suite of 20 elemental constituents ( $\mathrm{Al}, \mathrm{As}, \mathrm{B}, \mathrm{Ba}, \mathrm{Ca}, \mathrm{Cd}, \mathrm{Co}, \mathrm{Cr}$, $\mathrm{Cu}, \mathrm{Fe}, \mathrm{K}, \mathrm{Mg}, \mathrm{Mn}, \mathrm{Na}, \mathrm{Ni}, \mathrm{P}, \mathrm{Pb}, \mathrm{Si}, \mathrm{Sr}, \mathrm{Zn}$ ) with an ICP spectrometer (Jarrell-Ash 965 Inductively Coupled Plasma-Optical Emission Spectrograph) at the University of Georgia's Chemical Analysis Laboratory using EPA analytical method 6010 C. National Institute of Standards and Technology (NIST) plant standards (apple leaves) were used to confirm the proper calibration for the matrix.

\section{Statistical analysis}

Chl a, DMSP, DMSO, and the DMSO:DMSP ratio were compared among the 4 disturbance types and among the 3 marsh zones. In each case, we averaged the results from all subsamples of a given plant for statistical analysis. Each measure was analyzed using a 2-way split-plot (partially nested) analysis of variance (ANOVA), where disturbance type and zone were the between- and within (split)-plot fixed effects, respectively, and sites were considered the unit of replication. The significance of disturbance type was evaluated against the whole-plot error term (sites within disturbance type). The significance of zone and the interaction term zone $\times$ disturbance type were evaluated against the split-plot error term (sites within disturbance type $\times$ zone, i.e. the residual). The interaction term was used to evaluate the main (null) hypothesis in this study, which was that the effect of zone would be similar regardless of disturbance type (i.e. a non-significant effect supports the hypothesis). Because the split-plot model requires a complete dataset with no missing values, there were a few cases where values were filled in. In the case of affected areas where no plants were collected (all dieback sites, 2 snail sites), we used the 'edge' zone value for the missing 'affected' zone. These were considered conservative in that concentrations of DMSP, DMSO, and chl a were typically lower in the affected than in the edge zones of the other 13 sites, and because plants had died in affected areas of dieback sites. Tukey's multiple comparison post hoc tests were used to evaluate pairwise differences among disturbance, zone, and disturbance $\times$ zone factors. Factors and pairwise differences were considered significant when $\mathrm{p} \leq 0.05$.

In order to examine the full suite of elemental composition of Spartina alterniflora leaves, we used nonmetric multi-dimensional scaling (NMDS) (R statistical package, R Development Core Team 2011) to view how zones and disturbance types were separated based on Bray-Curtis distances. Analysis of similarity (ANOSIM) was used to detect whether there were significant overall differences in the group clustering of zone and disturbance type based on 1000 permutations of the data. A sequential Bonferroni significance post hoc test was used to examine differences within each factor (PAST statistical package, Hammer et al. 2001).

\section{RESULTS}

\section{DMSP and DMSO}

DMSP concentrations averaged $17.25 \pm 1.02(\mathrm{SE})$ and $10.86 \pm 0.78 \mu \mathrm{mol} \mathrm{g}{ }^{-1} \mathrm{FW}$ in healthy leaves and stems, respectively, whereas DMSO concentrations were an order of magnitude lower, averaging $0.99 \pm 0.14$ and $0.87 \pm 0.12 \mu \mathrm{mol} \mathrm{g}{ }^{-1} \mathrm{FW}$ in healthy leaves and stems (Table 1). These DMSP concentrations were within the range that has been previously reported in healthy Spartina alterniflora (Otte \& Morris 1994, Husband \& Kiene 2007, Kiehn \& Morris 2010). The DMSO concentrations observed here were as much as 2 to 3 times higher than the only other study in which they were measured (leaves: $\sim 0.60 \pm 0.20 \mu \mathrm{mol} \mathrm{g}^{-1}$ FW; stems: $\sim 0.36 \pm 0.15 \mu \mathrm{mol} \mathrm{g}{ }^{-1} \mathrm{FW}$; Husband \& Kiene 2007). The DMSP and DMSO concentrations found in the roots of $S$. alterniflora were much lower than those of leaves and stems, with means of $1.26 \pm$ 0.14 and $0.43 \pm 0.13 \mu \mathrm{mol} \mathrm{g}^{-1} \mathrm{FW}$, respectively, in healthy plants. What is more important for this study, however, is how these constituents varied with stress. 
Table 1. Spartina alterniflora. Mean (SE) of chlorophyll a (chl a), DMSP, and DMSO concentrations in leaves and stems collected in healthy, edge, and affected zones in dieback, horse, snail, and wrack disturbance types (see 'Materials and methods' for details of the disturbance types). The highest concentration of chl $a$, DMSP, or DMSO per zone is shown in bold, in order to highlight trends. Each mean represents $\mathrm{N}=15$ for chlorophyll and $\mathrm{N}=10$ for DMSP and DMSO in leaves and stems (except at wrack sites, where $\mathrm{N}=9$ for chlorophyll and $\mathrm{N}=6$ for DMSP and DMSO, and in the dieback affected area where '-' denotes no sample and ${ }^{\text {a }}$ denotes 1 sample)

\begin{tabular}{|c|c|c|c|c|c|c|c|}
\hline $\begin{array}{l}\text { Disturbance } \\
\text { type }\end{array}$ & Zone & $\begin{array}{c}\text { Leaf } \mathrm{chl} \mathrm{a} \\
-\left(\mathrm{mg} \mathrm{g}^{-1}\right.\end{array}$ & $\begin{array}{l}\text { Stem chl a } \\
\text { sh wt) }\end{array}$ & Leaf DMSP & 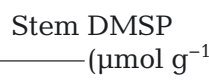 & $\begin{array}{l}\text { Leaf DMSO } \\
\text { resh wt) }\end{array}$ & Stem DMSO \\
\hline Dieback & $\begin{array}{l}\text { Affected } \\
\text { Edge } \\
\text { Healthy }\end{array}$ & $\begin{array}{c}- \\
0.389(0.052) \\
\mathbf{0 . 4 8 1}(\mathbf{0 . 0 5 5})\end{array}$ & $\begin{array}{c}- \\
0.073(0.020) \\
\mathbf{0 . 0 7 5}(\mathbf{0 . 0 1 0})\end{array}$ & $\begin{array}{c}- \\
13.45(3.62) \\
\mathbf{1 7 . 4 4}(\mathbf{2 . 4 1 )}\end{array}$ & $\begin{array}{c}0.36(0)^{\mathrm{a}} \\
8.35(1.67) \\
\mathbf{1 2 . 2 7 ( 2 . 1 4 )}\end{array}$ & $\begin{array}{c}- \\
\mathbf{1 . 0 6}(\mathbf{0 . 3 0 )} \\
1.05(0.28)\end{array}$ & $\begin{array}{c}0.11(0)^{\mathrm{a}} \\
0.68(0.09) \\
\mathbf{1 . 0 5}(\mathbf{0 . 2 9 )}\end{array}$ \\
\hline Horse & $\begin{array}{l}\text { Affected } \\
\text { Edge } \\
\text { Healthy }\end{array}$ & $\begin{array}{l}\mathbf{0 . 8 0 3}(\mathbf{0 . 0 4 5}) \\
0.744(0.054) \\
0.688(0.078)\end{array}$ & $\begin{array}{l}\mathbf{0 . 1 0 8}(\mathbf{0 . 0 2 4}) \\
0.102(0.017) \\
0.095(0.013)\end{array}$ & $\begin{array}{l}11.32(0.97) \\
12.56(1.53) \\
\mathbf{2 1 . 7 4}(\mathbf{2 . 4 8 )}\end{array}$ & $\begin{array}{l}4.37(0.76) \\
6.66(1.36) \\
\mathbf{9 . 4 3}(\mathbf{1 . 5 9 )}\end{array}$ & $\begin{array}{l}1.25(0.36) \\
0.63(0.09) \\
\mathbf{1 . 6 6}(\mathbf{0 . 4 2})\end{array}$ & $\begin{array}{l}0.61(0.16) \\
047(0.11) \\
\mathbf{0 . 8 6}(\mathbf{0 . 2 3})\end{array}$ \\
\hline Snails & $\begin{array}{l}\text { Affected } \\
\text { Edge } \\
\text { Healthy }\end{array}$ & $\begin{array}{c}0.231(0.069) \\
0.43(0.052) \\
\mathbf{0 . 4 3 8}(\mathbf{0 . 0 3 6})\end{array}$ & $\begin{array}{l}0.049(0.013) \\
0.059(0.010) \\
\mathbf{0 . 0 8 4}(\mathbf{0 . 0 1 4})\end{array}$ & $\begin{array}{l}10.71(3.48) \\
\mathbf{1 5 . 6 1}(\mathbf{1 . 2 7 )} \\
14.97(1.22)\end{array}$ & $\begin{array}{c}5.34(1.79) \\
8.04(1.60) \\
\mathbf{1 1 . 1 6}(\mathbf{1 . 5 8 )}\end{array}$ & $\begin{array}{l}\mathbf{0 . 9 0}(\mathbf{0 . 2 0}) \\
0.50(0.08) \\
0.57(0.08)\end{array}$ & $\begin{array}{l}0.26(0.06) \\
0.37(0.08) \\
\mathbf{1 . 0 6}(\mathbf{0 . 3 0 )}\end{array}$ \\
\hline Wrack & $\begin{array}{l}\text { Affected } \\
\text { Edge } \\
\text { Healthy }\end{array}$ & $\begin{array}{l}0.479(0.042) \\
0.422(0.030) \\
\mathbf{0 . 4 8 4}(\mathbf{0 . 0 3 0 )}\end{array}$ & $\begin{array}{l}0.063(0.010) \\
0.058(0.014) \\
\mathbf{0 . 0 7 8}(\mathbf{0 . 0 1 4})\end{array}$ & $\begin{array}{l}10.13(1.64) \\
\mathbf{1 7 . 8 1}(\mathbf{3 . 0 4 )} \\
15.22(2.11)\end{array}$ & $\begin{array}{l}12.21(\mathbf{2 . 2 5}) \\
11.99(1.58) \\
10.30(0.99)\end{array}$ & $\begin{array}{l}0.80(0.26) \\
\mathbf{0 . 9 3}(\mathbf{0 . 3 7}) \\
0.67(0.10)\end{array}$ & $\begin{array}{l}\mathbf{1 . 9 3}(\mathbf{0 . 8 8}) \\
0.76(0.23) \\
0.51(0.08)\end{array}$ \\
\hline
\end{tabular}

DMSP concentrations in both leaves and stems varied significantly by zone (a proxy for stress), but not by disturbance type (Tables $1 \& 2$ ). We found significantly lower DMSP concentrations in the affected compared to healthy and edge zones in leaves $(\mathrm{p}=$ 0.0026) and stems ( $p=0.0127)$, with the only exception being stems from wrack sites, which had higher DMSP concentrations in the affected zone. There was also no difference in the effect of zone $\times$ disturbance type, indicating that the effect of zone on the DMSP concentrations of leaves and stems was similar, regardless of disturbance type.

Patterns of DMSO concentrations in leaves and stems across zone were often similar to those observed for DMSP concentrations (Table 1). This was especially true for stems, where DMSO concentrations in each of the 4 disturbance types were highest in zones where DMSP concentrations were also highest. However, DMSO concentrations in leaves and stems did not vary significantly by zone or disturbance type (Table 2). The concentration of DMSP was a significant predictor of the DMSO concentrations in leaves $\left(\mathrm{p}<0.0001, \mathrm{r}^{2}=0.17\right)$ and stems $(\mathrm{p}<$ $\left.0.0001, r^{2}=0.17\right)$, but the relationships were much stronger when only the healthy zones were considered (healthy leaves: $\mathrm{p}<0.0001, \mathrm{r}^{2}=0.63$; healthy stems: $\left.\mathrm{p}<0.0001, \mathrm{r}^{2}=0.24\right)$.

The proportion of DMSO, and thus the ratio of leaf and stem DMSO:DMSP, varied significantly by zone but not by disturbance type (Table 2, Fig. 2). The ratio was significantly higher in the affected compared to healthy zones at horse, snail, and wrack sites both in leaves $(p<0.0001)$ and stems $(p=0.0056)$. In the case of dieback, where no leaves were available in the affected zone for comparison, the ratio was increased in plants from the edge zone. This pattern was strongest in the leaves compared to stems, where DMSP concentrations tended to be highest (DMSO concentrations were similar in leaves and stems), and thus the ratio had a greater variation between zones. There was no effect of zone $\times$ disturbance type, indicating that the effect of zone (a proxy for stress) on the DMSP:DMSO ratio in leaves and stems was similar, regardless of disturbance type. Roots had relatively low concentrations of both DMSP and DMSO, and the patterns of DMSO:DMSP were not as strong or consistent (see Table S1 in the supplement at www.intres.com/articles/suppl/m474p001_supp.pdf).

\section{Chl a}

The chl a concentrations measured in Spartina alterniflora ranged from 0.23 to $0.80 \mathrm{mg} \mathrm{g}^{-1} \mathrm{FW}$ for leaves (Table 1). The chl a content in leaves from healthy zones was similar to field values reported previously (0.6 $\mathrm{mg} \mathrm{g}^{-1} \mathrm{FW}$, Seneca \& Broome 1972; $0.76 \mathrm{mg} \mathrm{g}^{-1} \mathrm{FW}$, Piceno \& Lovell 2000), but slightly lower than those reported from plants grown in the greenhouse (Seneca \& Broome 1972, Pezeshki \& DeLaune 1993). Chl a content of stems was consistently 12 to $20 \%$ that of leaves of the same plant, ranging from 0.05 to $1.08 \mathrm{mg} \mathrm{g}^{-1} \mathrm{FW}$.

Chl a content was highest in stems and leaves in the healthy zones at all of the disturbance types, except for horse sites where concentrations were 
Table 2. Spartina alterniflora. Statistical summary of split-plot analyses of variance for testing the main effects disturbance type (between-plot factor) and zone (within-plot factor) on the variation in chlorophyll a (chl a), DMSP, DMSO, and the DMSO:DMSP ratio in leaves and stems of plants at the 20 survey sites. Disturbance type was evaluated against the whole-plot error term (sites within disturbance type), whereas zone and zone $\times$ disturbance type were evaluated against the split-plot error term (sites within disturbance type $\times$ zone, i.e. the residual). Values in bold are significant $(\mathrm{p}<0.05)$

\begin{tabular}{|c|c|c|c|c|c|c|c|}
\hline \multirow{2}{*}{\multicolumn{2}{|c|}{ Source of variation }} & \multicolumn{3}{|c|}{$\longrightarrow$ Leaves $\longrightarrow$} & \multirow{3}{*}{$\frac{\mathrm{df}}{3}$} & \multirow{3}{*}{$\begin{array}{c}\text { Stems } \\
\quad F \\
3.12\end{array}$} & \multirow{3}{*}{$\begin{array}{c}\mathrm{p} \\
0.0555\end{array}$} \\
\hline & & \multirow{2}{*}{$\begin{array}{r}\mathrm{df} \\
3\end{array}$} & \multirow{2}{*}{$\begin{array}{c}F \\
10.99\end{array}$} & \multirow{2}{*}{$\begin{array}{c}\mathrm{p} \\
\mathbf{0 . 0 0 0 4}\end{array}$} & & & \\
\hline Chl a & Disturbance type & & & & & & \\
\hline & Whole-plot error term & 16 & & & 16 & & \\
\hline & Zone & 2 & 0.61 & 0.5472 & 2 & 1.02 & 0.3704 \\
\hline & Zone $\times$ Disturbance type & 6 & 1.44 & 0.2310 & 6 & 0.54 & 0.7757 \\
\hline & Split-plot error term & 32 & & & 32 & & \\
\hline \multirow[t]{5}{*}{ DMSP } & Disturbance type & 3 & 0.29 & 0.8298 & 3 & 2.56 & 0.0917 \\
\hline & Whole-plot error term & 16 & & & 16 & & \\
\hline & Zone & 2 & 7.22 & 0.0026 & 1 & 5.02 & 0.0127 \\
\hline & Zone $\times$ Disturbance type & 6 & 1.19 & 0.3383 & 3 & 1.04 & 0.7561 \\
\hline & Split-plot error term & 32 & & & 16 & & \\
\hline \multirow[t]{5}{*}{ DMSO } & Disturbance type & 3 & 1.76 & 0.1947 & 3 & 2.2 & 0.1280 \\
\hline & Whole-plot error term & 16 & & & 16 & & \\
\hline & Zone & 2 & 1.45 & 0.2496 & 1 & 1.54 & 0.2308 \\
\hline & Zone $\times$ Disturbance type & 6 & 1.58 & 0.1837 & 3 & 3.77 & 0.0060 \\
\hline & Split-plot error term & 32 & & & 16 & & \\
\hline \multirow[t]{5}{*}{ DMSO:DMSP } & Disturbance type & 3 & 0.54 & 0.6622 & 3 & 1.02 & 0.4081 \\
\hline & Whole-plot error term & 16 & & & 16 & & \\
\hline & Zone & 2 & 11.81 & $<0.0001$ & 2 & 6.12 & 0.0056 \\
\hline & Zone $\times$ Disturbance type & 6 & 1.27 & 0.2997 & 6 & 0.19 & 0.9771 \\
\hline & Split-plot error term & 32 & & & 32 & & \\
\hline
\end{tabular}

Fig. 2. Spartina alterniflora. Ratio of DMSO: DMSP in leaves (top) and stems (bottom) in healthy, edge, and affected zones of dieback, horse, snail, and wrack disturbance types. The significance ( $p$-value) of the split-plot ANOVA factors zone (Z), disturbance type (D), and zone $\times$ disturbance type $(\mathrm{Z} \times \mathrm{D})$ are indicated by asterisks, where ${ }^{* *} \mathrm{p}<0.01,{ }^{* * * *} \mathrm{p}<0.0001$, and ns: not significant, and different letters after the zone labels indicate pairwise differences among zones (Tukey's multiple comparison test). nd: no data, $\dagger$ : 1 sample (not included in statistical analysis). Error bars represent $\mathrm{SE}$ calculated based on $\mathrm{N}=10$ plants zone $^{-1}$ at each disturbance type, except wrack sites where only 6 plants were available; ANOVAs were performed after averaging data from the 2 replicate plants analyzed at each site
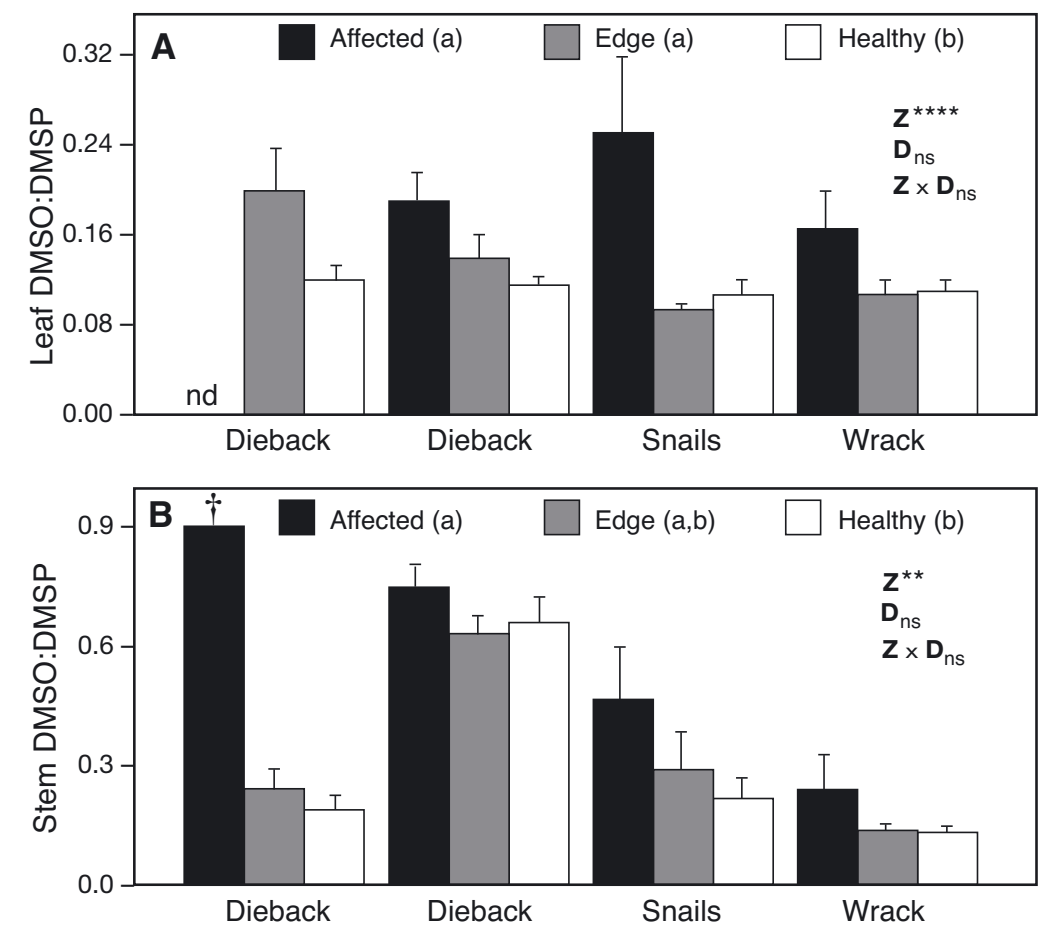

highest in the affected zone (no measurements were made in affected zones at dieback sites due to unavailability of plants). However, chlorophyll differences among zones within each disturbance type were typically fairly small, and zone was not signifi-

cant for either leaves or stems (Table 2). Disturbance type was a significant source of variation in leaf chlorophyll, with the horse sites having a higher overall mean concentration of chlorophyll (0.75 mg $\mathrm{g}^{-1} \mathrm{FW}$ ) compared to other disturbance types (which 
were all $\left.\leq 0.46 \mathrm{mg} \mathrm{g}^{-1} \mathrm{FW}\right)$. There was no significant interaction effect of zone $\times$ disturbance type.

Because senescing/yellowing plants have higher ratios of DMSO:DMSP (Husband \& Kiene 2007), we explored the relationship between chl $a$ and DMSO: DMSP using linear regression. Variation in chl a concentrations did not predict leaf $\left(\mathrm{N}=32 ; \mathrm{r}^{2}=0.06, \mathrm{~ns}\right)$ or stem $\left(\mathrm{N}=32 ; \mathrm{r}^{2}=0.03, \mathrm{~ns}\right)$ DMSO:DMSP ratios.

\section{Elemental composition (metals)}

The elemental composition of green Spartina alterniflora leaves generally fell within range of previous reports (Table 3 and Table S2 in the supplement), except for $\mathrm{B}, \mathrm{Cd}$, and $\mathrm{Co}$, which were approximately an order of magnitude higher than the limited number of previous observations.

The concentration of the 20 elemental trace metals examined exhibited a strikingly similar pattern among all of the disturbance types; the affected and edge zones had the highest concentrations for all 20 metal constituents in the dieback and horse sites, and for 19 of 20 metal constituents (all but K) in the snail and wrack sites (Table 3). The ratios of $\mathrm{Al}: \mathrm{K}$ and Fe:K were examined in order to make a comparison to those reported as elevated by McKee et al. (2004) in dieback areas of Louisiana $(\mathrm{Al}: \mathrm{K}, \sim 0.04-0.07$ and $\mathrm{Fe}: \mathrm{K}, \sim 0.06-0.10)$. The Al:K ratios in our study (0.1170.237 ) were about 2- to 3-fold higher than theirs, whereas our Fe:K ratios (0.05-0.11) were similar. However, relative to control areas, McKee et al. (2004) found these ratios to be 4 - to 6-fold higher in the dieback areas, whereas in our study the ratios in the affected zones were relatively similar to those in the healthy zones (only $\sim 2$-fold higher).

For the overall pattern of total metal composition in Spartina alterniflora, we used an NMDS to view how zones and disturbance types grouped (Fig. 3). Zones (especially the affected and healthy zones) were distinctly separate groups, whereas disturbance types were not (ANOSIM: zone, $\mathrm{p}=0.002, \mathrm{R}=0.33$; disturbance type, $p=0.14, \mathrm{R}=0.18$ ). In post hoc multiple comparisons, the healthy zone was significantly different from the edge and affected zones, whereas the edge and affected zones were not different from one another.

\section{DISCUSSION}

This study examined the variation of DMSP, DMSO, chl $a$, and metal concentrations in Spartina alterniflora as potential measures of physiological

Table 3. Spartina alterniflora. Mean tissue elemental composition of leaves ( $\mu \mathrm{g} \mathrm{g}^{-1}$ leaf dry weight) in healthy, edge, and affected zones at dieback, horse, snail, and wrack disturbance types (see 'Materials and methods' for details of the disturbance types). The number of sites that were averaged per zone for each disturbance type is indicated $(\mathrm{N})$. The highest concentration of each element per zone and disturbance type is shown in bold

\begin{tabular}{|c|c|c|c|c|c|c|c|c|c|c|c|c|}
\hline \multirow{4}{*}{$\begin{array}{l}\text { Disturbance type: } \\
\text { Zone: } \\
\mathrm{N} \text { (sites): } \\
\text { Element }\end{array}$} & \multicolumn{3}{|c|}{ Dieback } & \multicolumn{3}{|c|}{ Horse } & \multicolumn{3}{|c|}{ Snails } & \multicolumn{3}{|c|}{ Wrack } \\
\hline & Healthy & Edge & Affected & Healthy & Edge & Affected & Healthy & Edge & Affected & Healthy & Edge & Affected \\
\hline & 3 & 3 & 1 & 2 & 2 & 2 & 3 & 3 & 2 & 2 & 2 & 2 \\
\hline & & & & & & & & & & & & \\
\hline $\mathrm{Al}$ & 1016 & 1623 & 2368 & 1351 & 1901 & 1596 & 1545 & 1580 & 2399 & 1486 & 2493 & 2307 \\
\hline As & 0.21 & 0.29 & 0.37 & 0.27 & 0.38 & 0.33 & 0.28 & 0.28 & 0.41 & 0.24 & 0.37 & 0.37 \\
\hline B & 43.8 & 112.9 & 99.1 & 46.1 & 132.6 & 121.0 & 43.1 & 59.8 & 52.3 & 43 & 35 & 109 \\
\hline $\mathrm{Ba}$ & 0.00 & 0.00 & 3.56 & 1.94 & 2.28 & 2.14 & 1.00 & 0.42 & 2.36 & 0.00 & 0.18 & 0.45 \\
\hline Co & 0.84 & 1.05 & 0.91 & 1.10 & 1.75 & 1.40 & 0.94 & 0.97 & 1.39 & 0.87 & 1.04 & 1.50 \\
\hline $\mathrm{Cr}$ & 2.80 & 3.59 & 3.42 & 3.68 & 5.85 & 4.69 & 3.15 & 3.28 & 4.24 & 3.75 & 3.38 & 4.44 \\
\hline $\mathrm{Cu}$ & 1.56 & 2.98 & 2.83 & 2.15 & 5.23 & 7.73 & 1.54 & 1.98 & 2.43 & 1.76 & 2.19 & 3.21 \\
\hline $\mathrm{Fe}$ & 459 & 690 & 593 & 704 & 1086 & 842 & 589 & 613 & 640 & 552 & 808 & 542 \\
\hline K & 8670 & 8588 & 11040 & 11027 & 9975 & 12930 & 11825 & 11247 & 9035 & 11165 & 11145 & 9733 \\
\hline $\mathrm{Mg}$ & 2834 & 3892 & 3384 & 2503 & 4163 & 4022 & 3187 & 3826 & 5678 & 2132 & 3044 & 5050 \\
\hline Mn & 46.1 & 89.9 & 46.0 & 25.8 & 52.9 & 48.5 & 17.6 & 19.8 & 19.9 & 22 & 36 & 161 \\
\hline $\mathrm{Si}$ & 2935 & 4713 & 4588 & 5187 & 7815 & 7603 & 4100 & 4287 & 3691 & 3326 & 4079 & 3578 \\
\hline $\mathrm{Sr}$ & 38.1 & 50.3 & 43.0 & 20.1 & 32.3 & 35.6 & 43.6 & 44.6 & 69.2 & 33.9 & 44.0 & 66.5 \\
\hline $\mathrm{Zn}$ & 6.3 & 11.7 & 21.8 & 8.1 & 12.6 & 18.6 & 5.9 & 6.8 & 7.9 & 4.7 & 6.4 & 12.9 \\
\hline
\end{tabular}




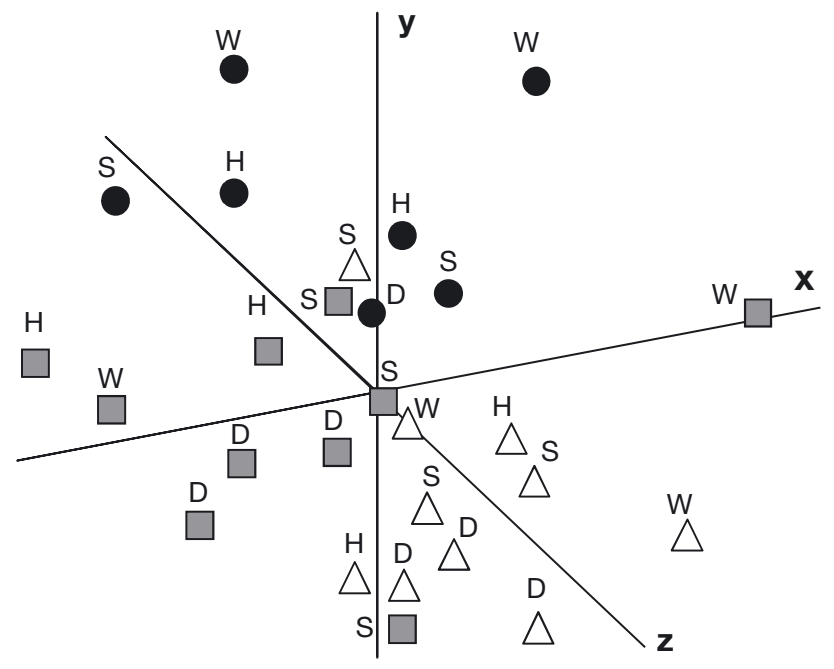

Fig. 3. Spartina alterniflora. Three-dimensional ordination (non-metric multidimensional scaling) grouped by salt marsh zone and disturbance site-type based on similarities (Bray-Curtis) in elemental composition in leaf tissues for the entire suite of constituents (20 elements). (0) Affected, ( $\square$ ) edge, and $(\Delta)$ healthy zones; D: dieback, H: horse, S: snail, and W: wrack sites. Stress: 0.07

stress in response to various disturbances. In all 4 disturbance types evaluated (sudden dieback, horse overgrazing, high snail density, and wrack), both foliar DMSO:DMSP ratios and the metal composition of $S$. alterniflora were significantly higher in affected compared to the healthy zones. Because these responses varied by zone (a proxy for degree of stress) but not by disturbance type, the DMSO:DMSP ratio and metal composition both appear to be general stress response indicators in $S$. alterniflora. In contrast, the individual components (DMSP, DMSO, or single metal species alone) were not as consistently different among zones. Chl a concentrations, which are typically used as a visible sign of stress, were the least sensitive of all measures and were not significantly different among zones.

\section{DMSP}

The function of DMSP in Spartina alterniflora remains unclear. DMSP concentrations have not been found to vary consistently with salinity, sulfides, or nitrogen, suggesting that it is unlikely to function as either a compatible solute or a sulfur detoxicant (Otte \& Morris 1994, Mulholland \& Otte 2000, 2001). It is possible that DMSP functions as a methylating agent, an herbivore deterrent, an intermediate in the synthesis of acrylic acid (or other compounds), or any combination of these (Otte \& Morris 1994), but more recent evidence suggests that it may act as an antioxidant in $S$. alterniflora, which is similar to its role in phytoplankton (Sunda et al. 2002, Husband \& Kiene 2007). Husband et al. (2012) observed increased oxidation of DSMP to DMSO in plants experimentally treated with the herbicides paraquat and 3-(3,4dichlorophenyl)-1,1-dimethylurea (DCMU), each of which generates reactive oxygen species (superoxide and singlet oxygen, respectively).

Foliar DMSP was found at decreased concentrations nearest sudden dieback areas in South Carolina (Kiehn \& Morris 2010) and in visibly stressed (yellowing) Spartina alterniflora in Alabama (Husband \& Kiene 2007). We observed a similar pattern of DMSP concentrations at the Georgia dieback sites examined here: leaves and stems taken from healthy zones, located approximately $10 \mathrm{~m}$ from the dieback, had higher concentrations of DMSP than did those collected from the edge zones. DMSP concentrations in both leaves and stems were also significantly decreased in the affected zones of the other 3 disturbance types, except for stems at wrack sites (it is possible that $S$. alterniflora was not as stressed at the wrack sites). These results suggest that DMSP may decrease in response to generic (oxidative) stress, rather than to a specific stressor.

\section{DMSO}

DMSO concentrations alone were not effective indicators of stress because they occurred at a very low concentration and the variation among zones was inconsistent or insignificant. The one other study to measure DMSO concentrations in Spartina alterniflora reported even lower mean concentrations than those observed here (Husband \& Kiene 2007). Less is known about the concentration of DMSO in $S$. alterniflora, and it may be that DMSO is highly variable across marshes. It is also possible that the conversion efficiency of DMSO to DMS was greater in the particular batch of $\mathrm{TiCl}_{3}$ reagent that we used. Kiene \& Gerard (1994) noted that when the reduction efficiency was low, $\mathrm{TiCl}_{3}$ often yielded as much as $30 \%$ less DMS from DMSO standards. Methodological differences could also account for differences between studies: Husband \& Kiene (2007) estimated DMSO from within the same serum vial (same plant sample) that was used to estimate DMSP, which required an additional degassing of DMS and neutralization (with $\mathrm{HCl}$ ) of the $\mathrm{NaOH}$ reagent (used to oxidize DMSP) in order for DMSO reduction to take 
place with $\mathrm{TiCl}_{3}$. If the $\mathrm{NaOH}$ is not fully neutralized, then the $\mathrm{TiCl}_{3}$ can react with it instead of reducing the DMSO, thereby leading to an underestimate of DMSO. Regardless of differences in the absolute value of DMSO, its concentrations were significantly related to those of DMSP in healthy $S$. alterniflora plants as was also noted by Husband \& Kiene (2007). Because DMSO is an oxidation product of DMSP, it is not surprising that the 2 are related. We found that DMSO typically accounted for about $\sim 3$ to $8 \%$ of leaf DMSP and $\sim 8$ to $9 \%$ of stem DMSP. In contrast to healthy zones, DMSP was not well-correlated with DMSO concentrations in the edge and affected zones. This suggests that disturbances likely affect the proportion of foliar DMSP that gets converted to DMSO (Husband \& Kiene 2007).

\section{DMSO:DMSP ratio}

If the proportion of DMSO varies with stress, then the ratio of DMSO:DMSP provides a useful way to make comparisons. In this study, $85 \%$ of the DMSO: DMSP ratios in leaves from the healthy zone were $<0.14$. Although there was overlap in the ranges of ratios from the healthy and affected zones, only the leaves from affected zones had ratios that exceeded 0.29 . These potential cut-offs would need to be further explored at other sites.

Husband \& Kiene (2007) first showed that the DMSO:DMSP value was higher in yellow and spotty, presumably stressed, leaves than in nearby healthy leaves. They suggested that the ratio may increase with senescence and the loss of plant pigment (yellowing). Although we found that the DMSO:DMSP ratio was significantly greater in the leaves and stems of affected zones, we did not find a significant relationship between the DMSO:DMSP ratio and chl a concentration, which suggests that the DMSO:DMSP ratio is responding to something other than senescence alone. The fact that the DMSO:DMSP ratio was significant across all disturbance types, however, shows that it is a potentially useful indicator no matter what caused the stress to Spartina alterniflora.

\section{Foliar metal concentration}

This study is among the first studies to view metal uptake as a symptom of stress, rather than the cause, and also among the first to examine the full suite of metals, rather than just focusing on a single or few specific metals of interest. Of the 19 metals (and P) evaluated in foliar tissues of Spartina alterniflora, nearly all cases (77 of 80 ) were higher in either the edge or affected zone compared to the healthy zone. Only K was higher in the healthy zone. McKee et al. (2004) found increased $\mathrm{Al}$ and $\mathrm{Fe}$ accumulation in $S$. alterniflora in response to sudden dieback in Louisiana. Mobility and bioavailability of metals in the soil can increase with decreased soil $\mathrm{pH}(\leq 5)$ and an oxidizing environment (Portnoy 1999). McKee et al. (2004) suggested that the drought conditions in Louisiana could have led to the observed decrease in soil $\mathrm{pH}(\sim 5)$, and that desiccation could have resulted in oxidizing conditions. However, no unusual $\mathrm{pH}$ or redox values were observed during sampling (the mean $\mathrm{pH}$ was 7.16 and the mean redox value was $-180 \mathrm{mV}$ in affected zones across all 4 disturbance types; McFarlin 2012). These results support the idea that metals were not a cause of stress, but rather were a symptom wherein plants accumulated metals under stressful conditions.

One possible scenario to explain the increased concentrations of metals in the disturbed areas is that under stress, plants often close their stomata (Maricle et al. 2007). Spartina alterniflora excludes metals through salt glands (Burke et al. 2000, Weis et al. 2002), but when stomata are closed, the reduced xylem pressure may inhibit the translocation and exclusion of ions from salt glands and thus increase metal concentrations in $S$. alterniflora tissues. It is also possible that there is increased metal translocation to leaves during stress. It has been documented that $S$. alterniflora leaves increase in metal concentration during senescence, which may also be a mechanism to reduce overall plant metal load as leaves are dropped (P. Weis et al. 2002, J. Weis et al. 2003). There is also the possibility that plants grow more slowly when stressed, yet accumulate metals at a similar rate to healthy plants, which could lead to an increased concentration (per unit weight) of metals in stressed plants.

Past studies have looked at increased foliar metals as a source rather than an indicator of stress. These have either reported the effects of metal toxicity on Spartina alterniflora in greenhouse studies (Mendelssohn et al. 2001, Mateos-Naranjo et al. 2008) or have examined metal accumulation in the field at polluted sites (Cambrollé et al. 2011, Salla et al. 2011). Across these studies, $S$. alterniflora was highly tolerant of soil metal contamination, able to hyperaccumulate metals, and capable of phytoremediation (Salla et al. 2011). Because our sites were located in pristine areas (Sapelo Island, a National Estuarine Research Reserve; and Cumberland Island, a National Sea- 
shore), contamination was unlikely to be the cause of the observed increase in foliar metals. In fact, very few of the metal concentrations observed here $(B$, Cd, and Co) were elevated compared to other studies that have reported foliar metals in S. alterniflora, and none exceeded the amounts that would be expected to cause toxicity (Mendelssohn et al. 2001, Plank \& Kissel 2011).

This study suggests that the metal suite is an indicator of stress in Spartina alterniflora. The NMDS analysis showed clear differences between the affected and healthy zones in their overall metal load, but there were no differences among disturbance types, suggesting that the response of $S$. alterniflora was similar, regardless of the initial cause of stress.

\section{Chl a}

Reduced chlorophyll content of Spartina spp. is often used in research studies as a symptom of stress (e.g. Mateos-Naranjo et al. 2008, Li et al. 2010). Although chlorophyll concentrations measured in the affected zones in this study were reduced by $47 \%$ in snail sites, it was surprising how little the chlorophyll concentrations were influenced by the other disturbance types. These results suggest that a reliance on chlorophyll content to indicate stress is not necessarily appropriate. This has also been observed in evaluations of salinity stress (Mateos-Naranjo et al. 2010), redox stress (Pezeshki \& DeLaune 1993), and $\mathrm{CO}_{2}$ stress (Mateos-Naranjo et al. 2010). We actually found that $S$. alterniflora plants disturbed by horses had increased chlorophyll content compared to the healthy zones at those sites, a trend opposite to that of the other disturbance types. Grazing is known to remove phenologically older plant material and stimulate regrowth of new, more photosynthetically active tissue from the meristem at the ground surface (Frank et al. 1998). In this case, it is likely that leaves collected from the affected zone were younger than those in healthy zones due to continuous grazing; younger leaves typically have greater chlorophyll content than older leaves (Šesták 1963). Piceno \& Lovell (2000) also found a similar effect of increased chlorophyll content in $S$. alterniflora leaves that had been experimentally clipped.

\section{CONCLUSIONS}

Many indicators of stress that have been suggested for Spartina alterniflora have been stressor- specific and therefore of limited utility. However, indicators capable of detecting stress in many situations, as well as under multi-stressor scenarios, would be much more useful tools for identifying areas potentially at risk. The results presented here suggest that both the DMSO:DMSP ratio and the overall metal composition are good integrative indicators of generic stress in the field, in that both responded consistently to different disturbance types and across multiple field sites. Because the DMSO:DMSP ratio was more than just a simple function of chlorophyll concentration (a proxy for senescence), and the metal composition was responsive in otherwise apparently healthy (green) leaves, both were also sensitive early indicators of stress. It may be that both the DMSO:DMSP ratio and the metal composition of $S$. alterniflora are responding to oxidative stress that can be caused by a wide range of disturbances, but more research is needed to understand the underlying mechanisms of these stress responses. It would also be useful to use experimentally controlled levels of stress as a way to augment the results presented here (where we assumed that the edges of the disturbance zones were areas with lower levels of stress) to determine whether there is a threshold in either of these responses. Nevertheless, these results provide 2 potential early indicators of stress that can be used in the field under a wide range of conditions and deserve attention in future studies.

Acknowledgements. We thank the Moran and Whitman labs at the University of Georgia for providing access to lab equipment, and L. K. Chan, C. Reisch, and R. Kiene for methodological advice for the analysis of DMSP and DMSO. We also thank J. Fry and D. Hoffman of Cumberland Island National Seashore for providing access to field sites. The helpful comments from S. Pennings and 4 anonymous reviewers on early versions of the manuscript are also appreciated. This research was supported by the Georgia Coastal Ecosystems LTER Project (NSF Award OCE0620959).

\section{LITERATURE CITED}

Alber M, Swenson EM, Adamowicz SC, Mendelssohn IA (2008) Salt marsh dieback: an overview of recent events in the US. Estuar Coast Shelf Sci 80:1-11

Alexander C (2008) Wrack assessment using aerial photography in coastal Georgia. Final report to the Georgia Coastal Zone Management Program, Department of Natural Resources, Coastal Resources Division, Brunswick, GA

Arar EJ, Collins GB (1997) In vitro determination of chlorophyll $a$ and pheophytin $a$ in marine and freshwater algae by fluorescence, Method 445.0. National Exposure 
Research Laboratory, Office of Research and Development, US Environmental Protection Agency, Cincinnati, $\mathrm{OH}$

Baldwin AH, Mendelssohn IA (1998) Response of two oligohaline marsh communities to lethal and nonlethal disturbance. Oecologia 116:543-555

Bertness MD, Shumway SW (1993) Competition and facilitation in marsh plants. Am Nat 142:718-724

Burke DJ, Weis JS, Weis P (2000) Release of metals by the leaves of the salt marsh grasses Spartina alterniflora and Phragmites australis. Estuar Coast Shelf Sci 51:153-159

> Cambrollé J, Mateos-Naranjo E, Redondo-Gómez S, Luque T, Figueroa ME (2011) The role of two Spartina species in phytostabilization and bioaccumulation of $\mathrm{Co}, \mathrm{Cr}$, and $\mathrm{Ni}$ in the Tinto-Odiel estuary (SW Spain). Hydrobiologia 671:95-103

Evers DE, Sasser CE, Gosselink JG, Fuller DA, Visser JM (1998) The impact of vertebrate herbivores on wetland vegetation in Atchafalaya Bay, Louisiana. Estuaries 21:1-13

Ewanchuk PJ, Bertness MD (2003) Recovery of a northern New England salt marsh plant community from winter icing. Oecologia 136:616-626

Ewing K, McKee KL, Mendelssohn IA, Hester M (1995a) A comparison of sub-lethal nutrient stress in the salt marsh grass, Spartina patens. Environ Exp Bot 35:331-343

Ewing K, McKee KL, Mendelssohn IA, Hester M (1995b) A comparison of indicators of sublethal salinity stress in the salt marsh grass, Spartina patens (Ait.) Muhl. Aquat Bot 52:59-74

Ewing K, McKee KL, Mendelssohn IA (1997) A field comparison of indicators of sublethal stress in the salt marsh grass Spartina patens. Estuaries 20:48-65

Frank DA, McNaughton SJ, Tracy BF (1998) The ecology of the Earth's grazing ecosystems: profound functional similarities exist between the Serengeti and Yellowstone. Bioscience 48:513-521

Hammer $\varnothing$, Harper DAT, Ryan PD (2001) PAST: paleontological statistics software package for education and data analysis. Palaeo Electron 4:1-9

Holdredge C, Bertness MD, Altieri AH (2009) Role of crab herbivory in die-off of New England salt marshes. Conserv Biol 23:672-679

Husband JD, Kiene RP (2007) Occurrence of dimethylsulfoxide in leaves, stems, and roots of Spartina alterniflora. Wetlands 27:224-229

Husband JD, Kiene RP, Sherman TD (2012) Oxidation of dimethylsulfoniopropionate (DMSP) in response to oxidative stress in Spartina alterniflora and protection of a non-DMSP producing grass by exogenous DMSP + acrylate. Environ Exp Bot 79:44-48

Jefferies RL, Rockwell RF, Abraham KF (2004) The embarrassment of riches: agricultural food subsidies, high goose numbers, and loss of Arctic wetlands-a continuing saga. Environ Rev 11:193-232

Kashem MA, Singh BR (2001) Metal availability in contaminated soils: I. Effects of flooding and organic matter on changes in Eh, pH and solubility of $\mathrm{Cd}, \mathrm{Ni}$ and $\mathrm{Zn}$. Nutr Cycl Agroecosyst 61:247-255

Kiehn WM, Morris JT (2010) Variability in dimethylsulfoniopropionate (DMSP) concentrations in Spartina alterniflora and the effect on Littoraria irrorata. Mar Ecol Prog Ser 406:47-55

Kiene RP, Gerard G (1994) Determination of trace levels of dimethylsulfoxide (DMSO) in seawater and rainwater. Mar Chem 47:1-12

Kocsis MG, Nolte KD, Rhodes D, Shen TL, Gage DA, Han- son AD (1998) Dimethylsulfoniopropionate biosynthesis in Spartina alterniflora-evidence that S-methylmethionine and dimethylsulfoniopropylamine are intermediates. Plant Physiol 117:273-281

Li R, Shi F, Fukuda K (2010) Interactive effects of various salt and alkali stresses on growth, organic solutes, and cation accumulation in a halophyte Spartina alterniflora (Poaceae). Environ Exp Bot 68:66-74

Maricle BR, Cobos DR, Campbell CS (2007) Biophysical and morphological leaf adaptations to drought and salinity in salt marsh grasses. Environ Exp Bot 60:458-467

Martin JL (2003) The effect of cattle grazing on the abundance and distribution of selected macroinvertebrates in West Galveston Island salt marshes. MS thesis, Texas A\&M University, College Station, TX

Mateos-Naranjo E, Redondo-Gómez S, Cambrollé J, Luque T, Figueroa ME (2008) Growth and photosynthetic responses to copper stress of an invasive cordgrass, Spartina densiflora. Mar Environ Res 66:459-465

Mateos-Naranjo E, Redondo-Gómez S, Andrades-Moreno L, Davy AJ (2010) Growth and photosynthetic responses of the cordgrass Spartina maritima to $\mathrm{CO}_{2}$ enrichment and salinity. Chemosphere 81:725-731

McFarlin CR (2012) Salt marsh dieback: the response of Spartina alterniflora to disturbances and the consequences for marsh invertebrates. PhD dissertation, University of Georgia, Athens, GA

McKee KL, Mendelssohn IA, Materne MD (2004) Acute salt marsh dieback in the Mississippi River deltaic plain: a drought-induced phenomenon? Glob Ecol Biogeogr 13: 65-73

Mendelssohn IA, McKee KL (1992) Indicators of environmental stress in wetland plants. In: McKenzie DH, Hyatt DE, McDonald VJ (eds) Ecological indicators, Vol 1. Elsevier, New York, NY, p 603-624

Mendelssohn IA, McKee KL, Kong T (2001) A comparison of physiological indicators of sublethal cadmium stress in wetland plants. Environ Exp Bot 46:263-275

Mulholland MM, Otte ML (2000) The effects of varying sulphate and nitrogen supply on DMSP and glycine betaine levels in Spartina anglica. J Sea Res 43:199-207

Mulholland MM, Otte ML (2001) The effects of nitrogen supply and salinity on [DMSP], [glycine betaine] and [proline] concentrations in leaves of Spartina anglica. Aquat Bot 71:63-70

$>$ Otte ML, Morris JT (1994) Dimethylsulphoniopropionate (DMSP) in Spartina alterniflora Loisel. Aquat Bot 48: 239-259

Padinha C, Santos R, Brown MT (2000) Evaluating environmental contamination in Ria Formosa (Portugal) using stress indexes of Spartina maritima. Mar Environ Res 49: 67-78

Pennings SC, Bertness MD (2001) Salt marsh communities. In: Bertness MD, Gaines SD, Hay M (eds) Marine community ecology. Sinauer, Sunderland, MA, p 289-316

Pennings SC, Wall VD, Moore DJ, Pattanayek M, Buck TL Alberts JJ (2002) Assessing salt marsh health: a test of the utility of five potential indicators. Wetlands 22:406-414

Pezeshki SR, DeLaune RD (1993) Effects of soil hypoxia and salinity on gas exchange and growth of Spartina patens. Mar Ecol Prog Ser 96:75-81

Piceno YM, Lovell CR (2000) Stability in natural bacterial communities: II. Plant resource allocation effects on rhizosphere diazotroph assemblage composition. Microb Ecol 39:41-48

Plank CO, Kissel DE (2011) Plant analysis handbook for Georgia. The Cooperative Extension Service, College of 
Agricultural and Environmental Sciences, University of Georgia, Athens, GA. Available at http://aesl.ces.uga. edu/publications/plant/ (accessed 15 October 2012)

Portnoy JW (1999) Salt marsh diking and restoration: biogeochemical implications of altered wetland hydrology. Environ Manag 24:111-120

R Development Core Team (2011) R: a language and environment for statistical computing (version 2.13.1). R Foundation for Statistical Computing, Vienna. Available at www.R-project.org.

Salla V, Hardaway CJ, Sneddon J (2011) Preliminary investigation of Spartina alterniflora for phytoextraction of selected heavy metals in soils from southwest Louisiana. Microchem J 97:207-212

Seneca ED, Broome SW (1972) Seedling response to photoperiod and temperature by smooth cordgrass, Spartina alterniflora, from Oregon Inlet, North Carolina. Chesapeake Sci 13:212-215

Šesták Z (1963) Changes in the chlorophyll content as related to photosynthetic activity and age of leaves. Photochem Photobiol 2:101-110

Silliman BR, Bertness MD (2002) A trophic cascade regulates salt marsh primary production. Proc Natl Acad Sci

Editorial responsibility: Ronald Kiene,

Mobile, Alabama, USA

\section{USA 99:10500-10505}

Silliman BR, van de Koppel J, Bertness MD, Stanton LE, Mendelssohn IA (2005) Drought, snails, and large-scale die-off of southern U.S. salt marshes. Science 310: 1803-1806

Sunda W, Kieber DJ, Kiene RP, Huntsman S (2002) An antioxidant function for DMSP and DMS in marine algae. Nature 418:317-320

Turner MG (1987) Effects of grazing by feral horses, clipping, trampling, and burning in a Georgia salt marsh. Estuaries 10:54-60

Valiela I, Rietsma CS (1995) Disturbance of salt-marsh vegetation by wrack mats in Great-Sippewissett Marsh. Oecologia 102:106-112

Weilhoefer CL (2011) A review of indicators of estuarine tidal wetland condition. Ecol Indic 11:514-525

Weis JS, Windham L, Weis P (2003) Patterns of metal accumulation in leaves of the tidal marsh plants Spartina alterniflora Loisel and Phragmites australis Cav. Trin ex Steud. over the growing season. Wetlands 23:459-465

Weis P, Windham L, Burke DJ, Weis JS (2002) Release into the environment of metals by two vascular salt marsh plants. Mar Environ Res 54:325-329

Submitted: July 30, 2012; Accepted: November 15, 2012 Proofs received from author(s): January 23, 2013 